\title{
Validating Halal Food Knowledge Dimensions Using Malaysian Non-Muslim Consumers Sample
}

\author{
Mas Wahyu Wibowo ${ }^{1}$, Fauziah Sh. Ahmad², Ali Hanafiah ${ }^{3}$, Ali Hanafiah ${ }^{4}$ \\ \{maswahyuwibowo@mercubuana.ac.id'1, fsa@ibs.utm.my², hamali2@live.utm.my3, \\ ali.hanafiah@mercubuana.ac.id $\left.{ }^{4}\right\}$ \\ Universitas Mercu Buana, Indonesia ${ }^{1}$, Universiti Teknologi Malaysia, Malaysia ${ }^{2}$, Universiti \\ Teknologi Malaysia, Malaysia ${ }^{3}$, Universitas Mercu Buana, Indonesia ${ }^{4}$
}

\begin{abstract}
The drivers of non-Muslim consumers in Malaysia to consume halal food have become one of the topics in halal studies. Those studies mostly mentioned that health benefits become the main reason for the non-Muslim consumers to consume halal food. However, there are still perceptions amongst the non-Muslim consumers that the Islamic slaughtering method is inhumane. Hence, the non-Muslim consumers' have an ambivalent evaluation towards halal food. To address this issue, halal food knowledge needs to be introduced to the non-Muslim consumers. However, since there are no empirical evidence regarding the dimensions of halal food knowledge, exploratory factor analysis is conducted to validate the structure and dimensionality of the construct by using SPSS version 21. Subsequently, the confirmatory factor analysis is performed to determine the dimensions of halal food knowledge in terms of theoretical validation through SmartPLS version 3.2.7. The results show that both health knowledge and animal friendly knowledge are the dimensions of halal food knowledge. In addition, the items are found to be reliable and meet the validity test criteria. Practical implications, future study suggestions, and methodological limitations are discussed.
\end{abstract}

Keywords: halal food, non-muslim consumers, scale validation, exploratory factor analysis, confirmatory factor analysis.

\section{Introduction}

Malaysian halal food sector is among the strongest performer in today's Islamic economy. Several factors facilitate its performance on the halal food sectors, such as strong government support, compliance with ISO methodologies of food production: Good Manufacturing Practice (GMP) and Hazard Analysis and Critical Control Point (HAACP), strict halal certification body, and globally recognized halal food production standard in MS 1500:2009 (1),(2). Further, Malaysian halal industry, including its halal food sector would be developed as one of the strategic area for the country's economic growth. Such economic development is stated within the RMK-11 (Rencana Malaysia Kesebelas), as the Malaysian government commitment to its halal food sector (3). The focus of RMK-11 is the global expansion of Malaysian halal products with the strong support from Malaysian Islamic finance infrastructure and halal ecosystem. The latter encompasses the inter-relatedness between the actors within the halal industry to create a business-friendly environment (Fezarudin et al., 2017) (4). There are five main pillars within the halal ecosystem, they are government support, infrastructure, human capital, reference center and products and services. Moreover, the halal 
ecosystem would provide a platform to develop the Malaysian halal industry into a source of economic growth as well as establishing an effective and efficient governance related to halal certification. As the result, Malaysia is ranked first and second for its halal food sector on 2017 and 2018, respectively (5). Such strong performance on halal food sector indicates that Malaysian halal food product is produced under strict procedure and certification system to be in line with the Sharia Laws. Therefore, Malaysian halal food is a product with high quality which intended not only for Muslim consumers, but for the non-Muslim consumers as well.

Indeed, halal food has attracted the non-Muslim consumers in Malaysia. Past study revealed that health attribute of halal food become the main reason among the non-Muslim consumers to consume the product (6). Health become the central feature for food consumption among non-Muslim in Malaysia, as reported by several studies. For example, health factor is the crucial consideration of choosing food among Malaysian Chinese (7). As for the Malaysian Indian counterpart, they prefer the freshness of ingredients as food safety consideration (8). In addition, the Indian consumers are active information seekers (8). Apart from the importance of health factors, another studies have reported a significant purchase power among the non-Muslims due to higher monthly income (9). Consequently, they are reported to have considerable monthly expenditures on food (Department of Statistics, 2015) (10). In this sense, halal food has a lucrative business opportunity to be marketed to the nonMuslim consumers segment.

However, although the health attribute of halal food has attracted the non-Muslim consumers, there is an issue that need further attention. Apparently, the non-Muslim consumers are faced with uncertainty when consuming halal food. That is, together with health benefits, the non-Muslim consumers perceive Islamic slaughtering method is considered as inhumane, which indicates an ambiguous evaluation of halal food by the nonMuslim consumers (11). Accordingly, such scholarly findings further confirm that lack of understanding on halal principles among the non-Muslim consumers become the crucial issue that need to be addressed (11),(12). In order to address this issue, halal food knowledge, particularly regarding health and animal friendly attributes, should be introduced to the nonMuslim consumers (11),(13). Moreover, as formulated within the MS 1500:2009, both attributes of health and animal friendly are strictly regulated in halal food production. Thus, referring to past studies, halal food knowledge that contains information of both health and animal friendly attributes are at the central to the non-Muslim consumers' understanding of the principles of halal food.

Following the discussion, this study is aimed to explore the halal food knowledge construct. Nevertheless, there is a lack empirical of empirical evidence regarding the health and animal friendly attributes as the dimension of halal food knowledge. Hence, the structure and dimensionality of the halal food knowledge construct could not be verified. To address such limitation, this study attempts to investigate the halal food knowledge as a multidimensional construct, followed by the validation of halal food knowledge scale by involving sample form non-Muslim shoppers in Malaysia. Exploratory factor analysis (EFA) and confirmatory factor analysis will be utilized as statistical techniques to validate halal food knowledge scales. The findings should make an important contribution to the field of halal food literature. 


\section{Literature Reviews}

\subsection{Knowledge (Brucks, 1985; Keller 1993)}

There are two prevalent concepts in consumer knowledge literatures. Firstly, Brucks (1985) distinguish consumer knowledge into OK and SK (14). OK is referred as the actual and accurate information of a product that is stored in the memory. OK involves the deliberation to engage and use of new additional information to perform a behavior (Aertsens et al., 2011) (15). Such new information includes sub-categorical product definition and facts (16). Meanwhile, SK refers to people's perception of the amount of information and closely related to self-assumed knowledge regarding a particular product (17). Accordingly, it would increase the level of their certainty in terms of decision making purposes (18). As confirmed by past studies, SK is a better predictor than OK for purchase-related behavior (18),(19). The reason is that SK also reflects the consumers' motivation as the representation of the alignment between their purchase-related behavior and their self-concept (20). Thus, although conceptually different, the relationship between both $\mathrm{OK}$ and SK would form the overall consumer knowledge on a product or service (16).

Secondly, Keller's (1993) concept of consumer knowledge is also referred as consumerbased brand equity (CBBE) (21). CBBE would occur if consumers have an adequate brand knowledge regarding a brand in both categories of product and service. Consumers' knowledge about a brand is the result of the exposure of the marketing activities and how they process such incoming information. Accordingly, consumers would be familiar, have a strong favorability and have unique associations toward a brand. Brand knowledge is defined as consumers' perception that is constructed through a mental process (22). In this regard, the attributes and benefits of a brand would be processed through learning, feeling, seeing and hearing. In turn, such mental processing would establish the consumers' association toward a brand (23). Hence, in a general, brand knowledge is a mental process that undertaken by consumers to process the incoming information which would generate their cognitive, affective and conative reactions (22),(23).

Taken together, the concept of knowledge from Brucks (1985) and Keller (1993) explain how consumers process any kind of information from various sources for their decision making. Within that process, consumers would align the information with their motives. Therefore, knowledge is defined as non-Muslim consumers' perceived knowledge regarding the attributes of a product that align with their motives (14),(21).

\subsection{Health and animal friendly attributes of halal food}

According Chamhuri and Batt (2015), halal food possesses credence attributes which contains aspects that considered as important by the consumers, however consumers could not directly experience the benefit even during and after consumption (24). In addition, such attributes could not be verified by consumers due to the lack of technical expertise (25). Personal values, attitudes, beliefs and knowledge are reported to become crucial for consumers' evaluation on the credence qualities due to lack of expertise by the consumers (26). Primarily, food credence attributes would include health and production method (27)]. The ethical values in food production method become the main concern for the consumers that involve environmental protection and animal welfare. In line with the Fernqvist and Ekelund (2014), Huy Tuu and Olsen (2012) and Moorman et al. (2004) and Rojas-Mendes et al., (2015) referred health attribute as the types of method conducted to ensure that the level of fat, 
fibre, sugar, salt and sodium content that are permissible to a certain extent (25),(28),(29),(30). Whereas Vanhonacker et al. (2007) referred the animal welfare attribute as the process of animal feeding, treatment, rearing and slaughtering methods that are associated with nutritious and healthy meat (31).

Halal food production also covers health and ecological aspects (environmental protection and animal friendly). From the health attribute standpoint, the application of GMP and HACCP indicates the growing demand of healthy food products among Malaysian consumers. It also suggest that a close inspection is conducted by Malaysian halal certification body (JAKIM) to ensure a high level of hygiene that and are free from any crosscontamination from toxic and unlawful substances (32). Meanwhile, from the animal friendly standpoint, The aim of Islamic slaughtering method is to cause death to the animals in a painless and immediate manner. Further, this method allows to drain blood from the animals as much as three times more than the non-Islamic procedure, which resulting in healthier meat because all bacteria and harmful elements are removed during the blood draining (11).

The non-Muslim consumers would align these attributes with their motives in purchasing halal food. Following the discussion, halal food knowledge would consist of two dimensions: health knowledge and animal welfare knowledge. Health knowledge is referred as the nonMuslim consumers' perceived knowledge regarding the health benefits of halal food based on a strict food production. Meanwhile, animal welfare knowledge is referred as the non-Muslim consumers' knowledge regarding the painless and immediate death of the animals by Islamic slaughtering method which also to drain blood faster to remove harmful bacteria. As such, halal food knowledge is operationally defined as non-Muslim consumers' level of perceived knowledge on the halal food attributes of health benefits and Islamic slaughtering method.

\section{Research Model, Hypotheses, and Methodology}

\subsection{Sample}

The target population is non-Muslim consumers that shop at 5 primary grocery stores located in Kuala Lumpur and Selangor. These grocery stores are Aeon, Aeon Big, Giant, Tesco, and Econsave (33). The non-Muslim consumers are more likely to be exposed to halal logo in a grocery store (34). The religious diversity with less Islamic influence upon nonMuslim communities make Kuala Lumpur and Selangor as an ideal location to generate lessbias response (35). Since there is no available list pertaining non-Muslim consumers' halal food consumption, a non-probability with judgmental sampling method would be applied in this study (36). Additionally, this study would involve the non-Muslim consumers without religious affiliation. The reason is that Christianism, Buddhism and Hinduism share the common value with halal principles of health and social-welfare aspects of food consumption (37). Overall, 400 questionnaires were distributed to conduct a separate evaluation for both EFA (200 samples) and CFA (200 samples).

\subsection{Instrumentation}

Items are based on conceptualization and operationalization of halal food knowledge construct as summarized on. Meanwhile, the questionnaire items for health attribute dimension is adapted from Huy Tuu and Olsen (2012) (4 items, $\alpha=0.79$ ) (28) and Moorman et al. (2004) ( 2 items, $\alpha=0.88$ ) (29). For animal welfare attribute dimension, the items are 
adapted from Vanhonacker et al. (2007) (4 items, $\alpha=0.93$ ) (31). In total, there are 10 items that will be used to measure each dimension. Examples of items used in this study are "I understand that strict inspection is conducted during halal food production to ensure its health benefits" (29) and "I understand that Islamic slaughtering method is intended for a painless death to the animal" (31).

Then, the items are assessed by five experts which contains two lecturers with the expertise within the field of marketing and consumer behavior. As for the practitioners, the panel consists of three experts whose basically academicians with doctoral degree, but involved directly with halal industry training and certification. that agreed to become panel for expert validity. The aim is to ensure that each items are align with the operational definition of each dimensions. These five experts consist of both academic and practitioner backgrounds with working experience on each respective fields for more than 5 years. The experts responded with positive feedback which indicated that the questions of each variable represent the operational definition. They recommended several adjustments, particularly on the technical terms. Another issue such as ineffective wordings, double barreled statement, repetition, consistency and flow also commented by the experts.

There are two items that are adjusted due to technical reasons: "I have enough information about the application of International Standard Operation (ISO) procedure of Hazard Analysis and Critical Control Point (HACCP) in Halal food production" and "I have enough information about the application of International Standard Operation (ISO) procedure of Good Manufacturing Practice (GMP) in Halal food production" into "I have enough information about the hazard prevention method in Halal food production" and "I have enough information about the hygiene condition of manufacturing premises in Halal food production". The initial 10 items are retained and adjusted as recommended by the experts.

Subsequently, pilot test were conducted to evaluate the performance of the questionnaire. For this purpose, the Bahasa Melayu version of the questionnaire was prepared. The pilot test were distributed to 100 non-Muslim shoppers on 5 mentioned above grocery stores which samples are excluded from this study. The questionnaire contains 7-point Likert scale, ranging from $1=$ strongly disagree, $2=$ disagree, $3=$ somewhat disagree, $4=$ neutral, $5=$ somewhat agree, $6=$ agree, $7=$ strongly agree. The Cronbach's $\alpha$ for each dimension are above the cut-off value of 0.7 , which indicates that the questionnaire is an adequate instrument for data collection.

\subsection{Data Collection Procedures}

Ethical and privacy issues are the primary consideration by ensuring anonymity and confidentiality of the respondents. Such ethical and privacy consideration was taken to reduce the respondents' potential discomfort when responding to the questionnaire. In addition, participation on voluntary basis was emphasized to further enhance the respondents' engagement with the questionnaire. For the purpose of data collection, the researcher was granted the permission by each grocery store's operating manager.

\subsection{Sample Demographic Characteristics}

Female sample is the dominant group compare to the male sample. The majority of the respondents are either work on the private sector or self-employed. The majority of monthly income range between RM 1.500 - RM 4.500. Lastly, the Chinese dominates the ethnicity group of the respondents compare to the Indian counterpart. All respondents are non-Muslim. As indicated earlier, the sample was separated into two subsamples to conduct the EFA and 
CFA, as recommended by Thien et al. (2014) (38). Each factor analysis would use equally 200 samples and within the range as suggested by Hair et al. (2010) (39).

\subsection{Data Analysis Techniques}

In this study, EFA were conducted by using the SPSS version 21. Whereas for CFA, this study used SmartPLS version 3.2.7. Hair et al. (2017) suggested that SmartPLS is a sufficient statistical software to conduct CFA besides AMOS (40). The difference is that AMOS computed the covariances among investigated constructs, hence, it requires model fit assessment as one of the criteria when conducting CFA (41). Meanwhile, SmartPLS emphasized on unique variance of each construct, and therefore, model fit assessment is not required (42),(40). Thus, the data analysis would be conducted on two stages.

Stage 1. EFA is conducted to analyze the structure and dimensionality of Halal Food Knowledge construct because of the following reasons. Firstly, although the construct has a theoretical support, its lack of empirical evidence might prevent the validity and reliability on the later stage of analysis. Secondly, since health benefits and animal friendly aspects of halal food is the concern of the HFK construct, EFA is necessary to assess whether there is such dimensionality within the construct [13],(43). The principal component analysis (PCA) with Varimax rotation would be performed to extract the dimensions within the HFK construct (43). Another parameter such as KMO and Bartlett's test of sphericity would also be assessed as the adequacy test for dimension extraction. The cut-off value to be fulfilled for the adequacy test is above 0.50 for KMO. Whereas Bartlett's test of sphericity requires below 0.50 for factor analysis significance.

Stage 2. After EFA, the subsequent analysis performed is CFA to determine both convergent and discriminant validity. Convergent validity is the degree of correlation of a particular item with other items within the same construct (44). The items are considered as an individual set of measurement to measure one particular construct. To establish convergent validity, there are two criteria to be considered: (1) outer loading; (2) average variance extracted (AVE) (44). Outer loadings indicate that the construct's indicators are similar. To achieve a high level of outer loading, the suggested cut-off value is between 0.5 and 0.708 or higher (44). Meanwhile, AVE is the communality of the construct. Applying the similar concept of the outer loading, the value of AVE of 0.50 and above indicates that the construct defines more than fifty percent of the variance of its items and vice versa (44),(45). Another criteria for convergent validity is composite reliability $(\mathrm{CR})$ that should be higher than 0.70 . In terms of discriminant validity, the purpose is to determine that one particular construct is truly separate from other constructs (44),(45) Fornell-Larcker criterion is used in this study along with the Heterotrait-Monotrait (HTMT) ratio with the threshold value of 0.85 for HTMT (46).

\subsection{Results EFA}

The 10 items of Halal Food Knowledge within the questionnaire used to measure the dimensions of Health Knowledge and Animal Friendly Knowledge. The purpose is to extract those dimensions from the Halal Food Knowledge construct. The value of KMO test is 0.864, which exceeded the cut-off value of 0.50 . The Bartlett's Test of Sphericity value is 0.000 , also below the cut-off value of 0.50 . Since the factor analysis is considered as adequate, the dimension extraction could be conducted. In this regard, Principal Component Analysis (PCA) with Varimax rotation are used to conduct EFA. In order for any dimension within the HFK 
construct to be established, several criteria should be fulfilled. The eigenvalue should be greater than 1. Further, the factor loading of the items should be greater than 0.50. Similarly, communalities of each item should exceed 0.50 .

The EFA was conducted on three rounds. During the first round, items HFK10, HFK8, HFK 7 and HFK9 are loaded into one factor. These items addressed the animal friendly aspects of halal food with Islamic slaughtering method as the main concern. Similarly, items HFK4, HFK3, HFK2, HFK6 and HFK5 are loaded into a different factor. These items contain the health aspects of halal food with the hygienic and hazard prevention of the food production as the main concern. The factor loading values and communalities of both dimensions are above the cut-off value of 0.50 as recommended by Hair et al. (2010) [13]. Meanwhile, alpha values are above 0.60 and the total variance explained are $78.7 \%$. However, item HFK1 seems to load into a different factor and separated from the other items. Its factor loading value is high (0.948) which signifies high redundancy. Furthermore, single item within a construct is not recommended to be included for further analysis because the stability of the construct might be compromised [13]. Following the argument, HFK1 would be removed from the HFK construct. After deciding the removal of HFK1, factor analysis was conducted for the second round. With the removal of HFK1, only two factors or dimensions are revealed for the HFK construct. The factor loading values of the items are also above the cut-off value of 0.50 . However, the communality value of item HFK5 is below the cut-off value of 0.50 . According to Hair et al. (2010), low communality indicates that the item does not share the same theme with other items [13]. The communality is important for reflectively specified construct as the construct is manifested by the measurement items (47). Hence, although item HFK5 has a strong factor loading value of .617 , its low value of communality $(0.469)$ value does not meet the theoretical requirement of a reflectively specified construct. Following this reasoning, item HFK5 is removed from the HFK construct. Similar with previous procedure, the factor analysis is conducted for the third round without both HFK1 and HFK5. After removal of HFK5, the communalities values are improved which indicates a theoretically sound reflective construct. The result from the EFA is available at the Appendix.

The result of the EFA revealed the dimensionality of the HFK construct as expected from the theoretical domain. That is, HFK is manifested by its health and animal friendly aspects. EFA revealed that items HFK7, HFK8, HFK9 and HFK10 are loaded into component or factor 1. Hence, factor 1 would be labeled as animal friendly knowledge (AFKNOW). On the other hand, items HFK2, HFK3, HFK4 and HFK6 are loaded into component or factor 2. Thus, factor 2 would be labeled as health knowledge (HKNOW). Taken together, EFA has extracted 2 dimensions from the HFK construct: HKNOW and AFKNOW. Also, 2 items were removed (HFK1 and HFK5) during the procedure with 8 items remaining out of initial 10 items. The Cronbach's $\alpha$ values signified the stability of both dimensions. Finally, the communality values of each item suggest that each dimension is a proper reflective construct. Therefore, HFK would be manifested by two dimensions: health knowledge (HKNOW) and animal friendly knowledge (AFKNOW).

\subsection{Results CFA}

The CFA was conducted by using SmartPLS version 3.2.7. The result revealed that factor loadings for all items are within the range between 0.5 and 0.708 or higher. The AVE also meet the cut-off value of above 0.5 for both Health Knowledge and Animal Friendly Knowledge. Meanwhile, the CR values for both dimensions also meet the cut-off value of above 0.7 . In addition, the path coefficient of 0.797 and 0.93 for Health Knowledge and 
Animal Knowledge, respectively, indicates that both dimensions are indeed the reflection of Halal Food Knowledge. The discriminant validity was evaluated by using both Fornell and Larcker criterion and HTMT ratio. The result fro SmartPLS shows that all square roots of AVE were greater than the corresponding correlation between dimensions of Halal Food Knowledge. In this case, both Health Knowledge and Animal Friendly Knowledge are discriminant with one another. Additionally, HTMT ratio was also assessed to determine the discriminant validity for both dimensions. Following the threshold value of below 0.85 as suggested by Henseler et al. (2015), the result from SmartPLS indicates that all values are below the cut-off value. Thus, both Health Knowledge and Animal Friendly Knowledge are truly distinct (46).

\section{Results and Discussion}

The findings show that Halal Food Knowledge is a multi-dimensional construct. In this regard, Halal Food Knowledge consists the dimensions of both Health Knowledge and Animal Friendly Knowledge. In the attempt to obtain valid results, the EFA was conducted on three rounds. During which, 2 items were eliminated in order to meet the cut-off value. Subsequently, the CFA was conducted to ensure the theoretical appropriateness of the Halal Food Knowledge dimensions. Findings in this study corresponds to the need of halal food knowledge introduction towards the non-Muslim consumers (Golnaz et al., 2010; Jamal and Sharifuddin, 2015), that might reduce their ambivalence evaluation toward the product (34),(13). As a result, the validation of both Health Knowledge and Animal Friendly Knowledge as the dimensions of Halal Food Knowledge would contribute to the literature of halal food as an emerging field of expertise among academics. The validated scale could be used for practical purposes. It is suggested to use the validated scale as an informational basis of halal food product attributes, which are align with the food consumption criteria of the nonMuslim consumers in Malaysia. Moreover, the introduction of such knowledge, in terms of informational basis, would reduce the uncertainty in halal food consumption among the nonMuslim consumers.

However, as a preliminary analysis, several limitation need to be addressed. This study focuses only on two attributes: health and animal friendly aspects of halal food. In this case, investigation regarding another attributes is strongly suggested that not only act as informational basis, but also to further validate Halal Food Knowledge as a construct. Further, future studies could also determine the Halal Food Knowledge dimensions based on different halal standards from another country. Such study could enrich our knowledge regarding the product attributes of halal food. In terms of questionnaire distribution, targeting another samples from different area in Malaysia could also be conducted to generate generalization of the validated scales. Lastly, another validity test could be conducted by future studies, such as nomological validity. The nomological validity that is represented in nomological network would provide another criteria to adequately determine the multidimensional structure of a construct.

\section{Conclusion}


As a conclusion, as halal food knowledge is considered to important to be introduced to the non-Muslim consumers, the scales validated in this study deserve to be the foundation to compare findings across studies on various settings. The 8 scales to measure Halal Food Knowledge along with its dimensions are found to be reliable and validated through a rigorous statistical analysis techniques. More importantly, findings of this study would set the foundation in the attempt to apprehend the Halal Food Knowledge as a construct.

\section{References}

1. Latif IA, Mohamed Z, Sharifuddin J, Abdullah AM, Ismail MM. A comparative analysis of global halal certification requirements. J Food Prod Mark. 2014;20(1):85101.

2. Arif S, Sidek S. Application of Halalan Tayyiban in the standard reference for determining Malaysian halal food. Asian Soc Sci. 2015;11(17):116.

3. Shariff SM, Jaafar HS, Muhammad A. Halal Supply Chain Deployment: Principles Versus Practices. Contemp Issues Dev Glob Halal Ind. 2016;457-69.

4. Fezarudin FZ, Tan MII, Saeed FAQ. Data visualization for human capital and Halal training in Halal industry using Tableau Desktop. Asian Simul Conf. 2017;

5. Reuters T, Standard D. https://www.salaamgateway.com/en/story/report_state_of_the_global_islamic_econo my_201718-SALAAM27112017104745/. Retrieved February 20, 2018. 2017.

6. Lee SH, Siong KC, Lee KS, Kim HS. Non-muslim customers' purchase intention on halal food products in malaysia. Culin Sci Hosp. 2016;22(1):108-16.

7. Yang CL, Khoo-Lattimore C, Lai MY. Eat to live or live to eat? Mapping food and eating perception of Malaysian Chinese. J Hosp Mark Manag. 2016;23(6):579-600.

8. Kumar S. Indian Consumers' Perception for Packaged Food and the Strategies of Food and Grocery Retailers in India-An Analysis. J Food Prod Mark. 2015;21(3):306-18.

9. Yusof SA. Household decision-making in Malaysia: The ethnic dimension. Soc Indic Res. 2015;124(1):283-93.

10. Malaysia D of S. https://www.dosm.gov.my/v1/index.php?r=column/cthemeByCat\&cat=323\&bul_id=c GpPdWw3REhucFZPdXRpek1Jd3FZUT09\&menu_id=amVoWU54UT10a21NWmdh MjFMMWcyZz09. Retrieved February, 20, 2018. 2015.

11. Rezai G, Mohamed Z, Shamsudin MN. Can halal be sustainable? Study on Malaysian consumers' perspective. J food Prod Mark. 2015;21(6):654-66.

12. Krishnan S. Mohamad Haniff Hanafi Mohd Aderis. Muhammad Nabil Azman. Mohammad Nazrin Azham Kamaluddin. “Halal Food: Study on Non-Muslim Acceptance. Am J Econ. 2017;7(1):41-5.

13. Jamal A, Sharifuddin J. Perceived value and perceived usefulness of halal labeling: The role of religion and culture. J Bus Res. 2015;68(5):933-41.

14. Brucks M. The effects of product class knowledge on information search behavior. J Consum Res. 1985;12(1):1-16.

15. Aertsens J, Mondelaers K, Verbeke W, Buysse J, Van Huylenbroeck G. The influence of subjective and objective knowledge on attitude, motivations and consumption of organic food. Br food J. 2011;113(11):1353-578. 
16. Canziani B, Hwang J, Byrd ET. Further exploration of subjective knowledge in the wine sector. Int J Wine Bus Res. 2016;28(3):2016.

17. Vigar-Ellis D, Pitt L, Caruana A. Knowledge effects on the exploratory acquisition of wine. Int J Wine Bus. 2015;27(2):84-102.

18. Viot C. Subjective knowledge, product attributes and consideration set: a wine application. Int J Wine Bus. 2012;24(3):219-48.

19. Ro H, Kubickova M. The use of student subjects in hospitality research: insights from subjective knowledge. J Qual Assur Hosp Tour. 2013;14(4):295-320.

20. Lin Z, Filieri R. Airline passengers' continuance intention towards online check-in services: The role of personal innovativeness and subjective knowledge. Transp Res Part E Logist Transp. 2015;81:158-68.

21. Keller KL. Conceptualizing, measuring, and managing customer-based brand equity. J Mark. 1993;57(1):1-22.

22. Keller KL. Building strong brands in a modern marketing communications environment. J Mark Commun. 2009;15(2-3):139-55.

23. Keller KL. Understanding the richness of brand relationships: Research dialogue on brands as intentional agents. J Consum Psychol. 2012;22(2):186-90.

24. Chamhuri N, Batt PJ. Consumer perceptions of food quality in Malaysia. Br Food J. 2015;117(3):1168-87.

25. Fernqvist F, Ekelund L. Credence and the effect on consumer liking of food-A review. Food Qual Prefer. 2014;32:340-53.

26. Verain MC, Sijtsema SJ, Antonides G. Consumer segmentation based on foodcategory attribute importance: The relation with healthiness and sustainability perceptions. Food Qual Prefer. 2016;48(99-106).

27. Sautron V, Péneau S, Camilleri GM, Muller L, Ruffieux B, Hercberg S, et al. Validity of a questionnaire measuring motives for choosing foods including sustainable concerns. Appetite. 2015;87:90-7.

28. Huy Tuu H, Olsen SO. Certainty, risk and knowledge in the satisfaction-purchase intention relationship in a new product experiment. Asia Pacific J Mark Logist. 2012;24(1):78-101.

29. Moorman C, Diehl K, Brinberg D, Kidwell B. Subjective knowledge, search locations, and consumer choice. J Consum Res. 2004;31(3):673-80.

30. I R-MJ, Nestour M Le, Rod M. Understanding attitude and behavior of Canadian consumers toward organic wine. J Food Prod Mark. 2015;21(4):375-96.

31. Vanhonacker F, Verbeke W, Van Poucke E, Tuyttens F. Segmentation based on consumers' perceived importance and attitude toward farm animal welfare. Int $\mathbf{J}$ Sociol Agric Food. 2007;15(3):91-107.

32. Ab Talib MS, Hamid ABA, Zulfakar MH. Halal supply chain critical success factors: a literature review. J Islam Mark. 2015;6(1):44-71.

33. Terano R, Yahya R, Mohamed Z, Saimin SB. Consumers' Shopping preferences for retail format choice between modern and traditional retails in Malaysia. J Food Prod Mark. 2014;20(1):179-92.

34. Golnaz R, Zainalabidin M, Mad Nasir S, Eddie Chiew F. Non-Muslims' awareness of Halal principles and related food products in Malaysia. Int Food Res J. 2010;17(3):667-74.

35. Haque A, Sarwar A, Yasmin F, Tarofder AK, Hossain MA. Non-Muslim consumers' perception toward purchasing halal food products in Malaysia. J Islam Mark. 2015;6(1):133-47. 
36. Clark VLP, Creswell JW. Understanding research: A consumer's guide. 2014.

37. Fischer J. Manufacturing halal in Malaysia. Contemp Islam. 2016;10(1):35-52.

38. Thien LM, Razak NA, Ramayah T. Validating teacher commitment scale using a Malaysian sample. Sage open. 2014;4(2).

39. Hair J., Black W, Babin B, Anderson R. Multivariate data analysis: Global edition. 2010.

40. Hair J, Hollingsworth C., Randolph A., Chong AY. An updated and expanded assessment of PLS-SEM in information systems research. Ind Manag Data Syst. 2017;117(3):442-58.

41. Astini R, Sulistiyowati I. Pengaruh Destination Image, Travel Motivation, dan Kualitas pelayanan terhadap Kepuasan pengunjung (Studi Kasus pada Wisatawan Nusantara Muslim di Pantai Carita Pandeglang Banten). J Ilm Manaj dan Bisnis Mercu Buana. 2015;1(3).

42. Permana D. Tourist's Re-visit Intention from Perspective of Value Perception, Destination Image and Satisfaction. Eur Res Stud J. 2018;21(3):254-65.

43. Mooi, E. and Sarstedt M. A concise guide to market research: The Process, Data, and Methods Using IBM SPSS Statistics. Heidelb Springer-Verlag, Berlin Heidelb. 2011;

44. Hair J., Hult GT., Ringle C., Sarstedt M. A primer on partial least squares structural equation modeling (PLS-SEM). London: Sage Publications, Inc. 2014.

45. Hair J., Hult GT., Ringle C., Sarstedt M. A primer on partial least squares structural equation modeling (PLS-SEM). Sage Publ. 2016;

46. Henseler J, Ringle CM, Sarstedt M. A new criterion for assessing discriminant validity in variance-based structural equation modeling. J Acad Mark Sci. 2015;43(1):115-35.

47. Diamantopoulos A. Incorporating formative measures into covariance-based structural equation models. Mis Q. 2011;335-58.

\section{Appendix}

Table 1. EFA Result with the removal of HFK1 and HFK5

\begin{tabular}{|c|c|c|c|c|}
\hline Item & Communalities & Item Description & Label & $\alpha$ \\
\hline 2 & 0.725 & $\begin{array}{l}\text { I have enough information about the } \\
\text { hygiene condition of manufacturing } \\
\text { premises in Halal food production }\end{array}$ & \multirow{4}{*}{ Health Knowledge } & \multirow{4}{*}{0.858} \\
\hline 3 & 0.861 & $\begin{array}{l}\text { I have enough information about the } \\
\text { impact of hazard prevention method } \\
\text { in for health benefits }\end{array}$ & & \\
\hline 4 & 0.87 & $\begin{array}{c}\text { I have enough information about the } \\
\text { impact of hygiene condition of } \\
\text { manufacturing premises for health } \\
\text { benefits }\end{array}$ & & \\
\hline 6 & 0.616 & $\begin{array}{c}\text { I understand that strict inspection is } \\
\text { conducted during halal food } \\
\text { production to ensure its health } \\
\text { benefits }\end{array}$ & & \\
\hline
\end{tabular}




\begin{tabular}{|c|c|c|c|}
\hline $\mathbf{7}$ & 0.887 & $\begin{array}{r}\text { I understand that Islamic slaughtering } \\
\text { method is intended for a painless } \\
\text { death to the animal }\end{array}$ & \multirow{2}{*}{ Animal Friendly } \\
Knowledge & \multirow{2}{*}{$\begin{array}{r}\text { I understand that Islamic slaughtering } \\
\text { method is intended for an immediate } \\
\text { death to the animal }\end{array}$} & I understand that Islamic slaughtering \\
$\mathbf{9}$ & 0.901 & $\begin{array}{r}\text { method will allow for a quicker blood } \\
\text { draining to remove bacteria and } \\
\text { harmful elements }\end{array}$ & \\
\hline $\mathbf{1 0}$ & 0.81 & $\begin{array}{r}\text { I understand that animal friendly is } \\
\text { the main concern in Islamic } \\
\text { slaughtering method }\end{array}$ & \\
\hline
\end{tabular}

